\title{
PEMANFAATAN TELEGRAM BOT UNTUKAUTOMATISASI PENGGAJIAN DAN INFORMASI KARYAWAN PADA PT MCS
}

\author{
Muhammad Galih Adiwibawa ${ }^{1}$, Lusi Ariyani ${ }^{2}$, Aswin Saputra ${ }^{3}$ \\ Program Studi Teknik Informatika, Fakultas Teknik dan Ilmu Komputer, \\ Universitas Indraprasta PGRI \\ Jalan Raya Tengah No 80, Kelurahan Gedong, Pasar Rebo, Jakarta Timur \\ galihadiwibawa@gmail.com ${ }^{1}$, lusiariyani0312@gmail.com², saputraaswin133@gmail.com³
}

\begin{abstract}
Abstrak
Instant Messaging (IM) Telegram Messenger yang diluncurkan pada Agustus tahun 2013 menjadi salah satu aplikasi IM yang banyak digunakan oleh masyarakat di seluruh dunia. Kelebihan Telegram Messenger salah satunya menyediakan Application Programming Interface (API), salah satu API yang disediakan adalah fitur BOT. Implementasi Telegram Bot sudah mulai banyak digunakan, salah satu keunggulan BOT adalah menyediakan data ke pengguna yang tidak terbatas oleh waktu. Dari hasil analisa proses pengolahan data gaji karyawan pada PT Maxindo Content Solution (MCS) masih dilakukan secara manual dan sering terjadinya human error yang ditemukan dalam proses penggajian. Tujuan penelitian ini untuk mempermudah proses penggajian, membuat automatisasi penggajian dan membuat sistem yang terkomputerisasi untuk meningkatkan efisiensi kerja. Dalam penelitian ini, untuk membangun sistem tersebut menggunakan model penelitian grounded research berdasarkan data-data nyata yang ada di lapangan dimana pengumpulan data dilakukan dengan wawancara dan observasi. Hasil dari penelitian ini membuat sistem yang telah terkoneksi dengan WEB dan Telegram Bot yang menunjukkan bahwa karyawan dan manajemen dapat mengelola gaji, slip gaji, absensi dan melakukan pengajuan secara mudah.
\end{abstract}

Kata Kunci: Sistem, Penggajian, API, WEB, Telegram Bot.

Abstract

Telegram Messenger Instant Messaging (IM) launched in August 2013 became one of the most widely used IM applications by people around the world. One of the advantages of Telegram Messenger is that it provides an Application Programming Interface (API), one of the APIs provided is the BOT feature. The implementation of Telegram Bot has started to be widely used, one of the advantages of BOT is providing data to users that is not limited by time. From the analysis of the process of processing employee salary data at PT. Maxindo Content Solution (MCS) is still done manually and often the occurrence of human errors found in the payroll process. The purpose of this research is to facilitate the payroll process, make payroll automatization and create computerized systems to improve working efficiency. In this study, to build the system using grounded research model based on real data in the field where data collection is done by interview and observation. The results of this study create a system that has been connected to WEB and Telegram Bots that shows that employees and management can manage salaries, pay slips, attendance and make submissions easily.

Keywords: System, Payroll, API, WEB, Telegram Bot.

\section{PENDAHULUAN}

Menurut (Samsudin, 2010) Pengertian gaji adalah sesuatu yang terkait dengan uang yang diberikan kepada karyawan atau pegawai. Menurut (Malayu, 2012) Pengertian Karyawan adalah orang penjual jasa (pikiran atau tenaga) dan mendapat kompensasi yang besarnya telah ditetapkan terlebih dahulu. Semua hal dari pendataan karyawan, absensi, penggajian hingga pembuatan laporan penggajian karyawan masih dilakukan secara manual ditulis kedalam buku besar oleh HRD. Hal tersebut sering mengakibatkan hasil yang kurang teliti dan kurang efisien.

Berdasarkan hasil riset yang dilakukan oleh APJII (Asosiasi Penyelenggara Jasa Internet Indonesia) mengenai Penggunaan Internet di Indonesia pada tahun 2017, penggunaan perangkat smartphone terutama aplikasi chatting harus mendapatkan perhatian lebih.

Menurut (Sutabri, 2012) Data merupakan bentuk mentah yang belum dapat bercerita sehingga perlu diolah lebih lanjut 
Menurut (Laudon \& Laudon, 2014) Secara teknis sesuatu rangkaian yang kompnen-komponennya salion terkait yang mengumpulkan (dan mengambil kembali), memproses, menyimpan dan mendistribusikan informasi untuk mendukung pengambilan keputusan dan mengendalikan perusahaan.

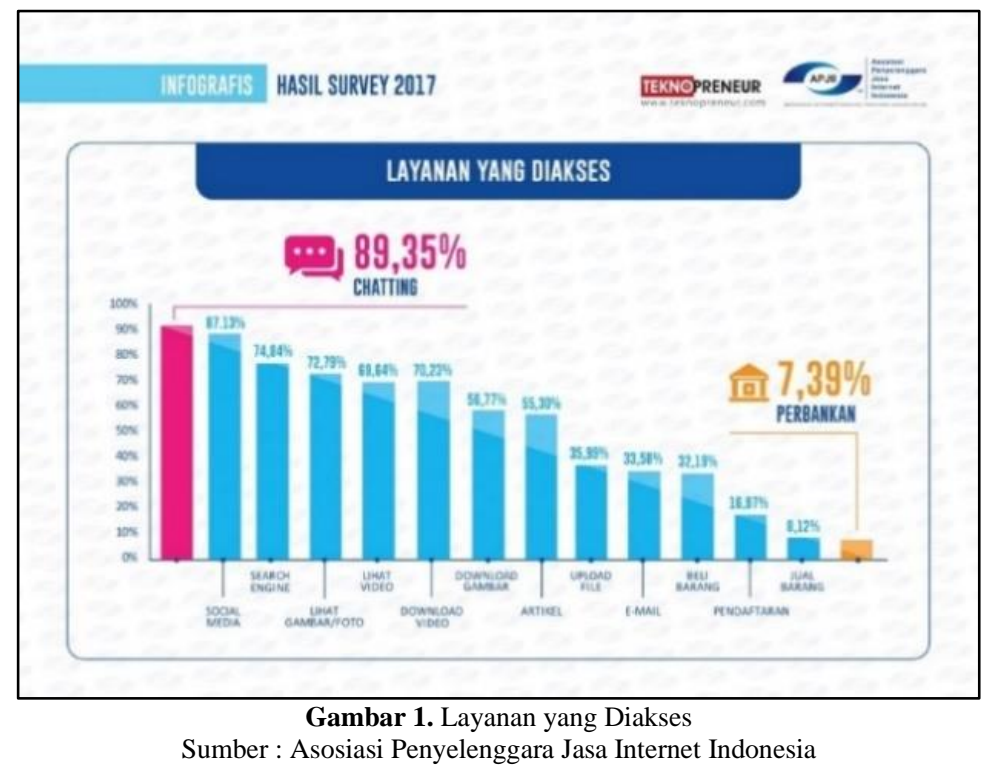

Telegram adalah aplikasi pesan instan berbasis cloud yang fokus pada kecepatan dan keamanan. Telegram dirancang untuk memudahkan pengguna saling berkirim pesan teks, suara, video, gambar, dan stiker dengan aman. Secara default, seluruh konten yang ditransfer akan dienkripsi berstandar internasional. Dengan demikian, pesan yang terkirim sepenuhnya aman dari pihak ketiga, bahkan dari Telegram sekalipun. Bukan hanya teks, gambar, dan video. Telegram juga bisa jadi sarana Anda mengirimkan dokumen, musik, berkas zip, lokasi real-time, dan kontak yang tersimpan di perangkat ke orang lain. Jika, orang yang dituju juga mempunyai aplikasi dengan akun Telegram terdaftar di perangkatnya. (Azhe, 2018).

Menurut (Anastasia \& Lilis, 2011) Sistem Informasi, yang kadang kala disebut sebagai sistem pemrosesan data, merupakan sistem buatan manusia yang biasanya terdiri dari sekumpulan kompenn (baik manual maupun berbasis komputer yang terintegrasi untuk mengumpulkan, menyimpan, dan mengelola data seta menyediakan informasi mengenai saldo persediaan.

Menurut (Ghifari et al., 2015) Otomasi adalah sekelompok elemen yang saling berhubungan, bekerja bersama, dan bergabung menjadi satu unit untuk mencapai tujuan tertentu.

Rumusan masalah dalam sistem penggajian pada PT Maxindo Content Solution antara lain: (1) Bagaimana sistem pengolahan data gaji yang sedang berjalan pada PT Maxindo Content Solution?, (2) Kenapa perancangan sistem informasi penggajian pada PT Maxindo Content Solution dibutuhkan?, (3) Bagaimana sistem pengolahan data gaji diolah ke sistem Telegram BOT?, (3) Bagaimana pengujian sistem informasi penggajian pada PT Maxindo Content Solution?.

Adapun tujuan penelitian adalah melakukan analisa sistem informasi penggajian pada PT Maxindo Content Solution, melakukan evaluasi pada pengolahan data gaji untuk mengefisienkan waktu sistem kerja yang baik dan memperoleh informasi tentang penggajian yang berkualitas. membangun schema database dan algoritma untuk mengkontrol sistem penggajian melalui aplikasi berbasis WEB yang terhubung dengan Telegram BOT, merancang dan menerapkan sistem penggajian yang terkomputerisasi sebagai solusi terhadap masalah yang dihadapi oleh PT Maxindo Content Solution.

Manfaat Penelitian yang didapatkan dalam penelitian ini yaitu dapat membantu sistem penggajian pada PT Maxindo Content Solution secara komputerisasi melalui aplikasi penggajian secara mudah dan efisien, mempercepat dalam pencarian sistem penggajian pegawai yang sesuai guna mendukung kemajuan yang dapat mempermudah membuat laporan sistem informasi pengajian dan pendataan laporam keuangan perusahaan untuk gaji karyawan semakin jelas dan transparan, 
perhitungan dan pencatatan detail gaji pokok dan bonus lebih spesifik sesuai dengan aturan, merancang dan menerapkan sistem penggajian yang terkomputerisasi sebagai solusi terhadap masalah yang dihadapi oleh PT. Maxindo Content Solution.

\section{PENELITIAN RELEVAN}

Hasil penelitian relevan sebelumnya sesuai dengan penelitian ini adalah penelitian oleh (Cokrojoyo et al., 2017). Yang berjudul "Pembuatan BOT Telegram untuk Mengambil Informasi dan Jadwal Film Menggunakan PHP”, menunjukan untuk membuat informasi jadwal film menggunakan telegram bot yang mana pengguna hanya butuh mengirimkan perintah ke akun Bot dan jadwal jam tayang akan diberikan ke pengguna yang membutuhkan. Persamaan penelitian di atas dengan penelitian ini, yaitu penggunaan telegram bot untuk alat kontrol otomatis sebuah sistem. Perbedaan penelitian ini dengan penelitian peneliti, yaitu metode yang digunakan menggunakan Webhook, sedangkan peneliti menggunakan metode long polling.

Hasil penelitian (Rochim, 2016). Yang berjudul "Rancang Bangun Telegram BOT pada Telegram Messanger dengan Metode Long Polling untuk Koperasi Kopma UGM", menunjukan bahwa membangun sebuah Telegram Bot untuk Koperasi Kopma UGM menggunakan metode komunikasi Long Polling untuk dapat diimplementasikan sesuai dengan kondisi infrastruktur Koperasi Kopma UGM. Persamaan penelitian di atas dengan penelitian peneliti, yaitu menerapkan pemaanfaatan Telegram Bot dengan metode long poling. Perbedaan penelitian di atas dengan penelitian peneliti, yaitu kegunaan untuk Koperasi Kopma UGM dan penggajian karyawan. Rochim, H. N. (2016). Rancang Bangun Telegram BOT pada Telegram Messanger dengan Metode Long Polling untuk Koperasi Kopma UGM.

\section{METODE PENELITIAN}

Dalam penelitian ini, peneliti tentu mengumpulkan data-data sebagai pendukung penelitian. Dalam mengumpulkan data, peneliti menggunaan beberapa metode, yaitu:

1. Metode Dokumentasi

Metode ini dilakukan peneliti untuk mendapatkan data dan informasi yang diperlukan dalam pemograman basis data diantaranya adalah:

a. Metode Pengamatan (Observation)

Peneliti mengamati secara langsung terhadap kegiatan yang dilakukan di PT Maxindo Content Solution agar dapat mengetahui setiap proses yang dikerjakan oleh para karyawan.

b. Wawancara (Interview)

Secara langsung berinteraksi dan melakukan tanya jawab dengan pihak-pihak PT Maxindo Content Solution yang berhubungan langsung dengan masalah yang diteliti.

c. Studi Pustaka (Library Research)

Peneliti mengumpulkan data dari buku yang berkaitan dengan masalah yang akan dibahas.

2. Metode Kualitatif

Metode ini dilakukan dengan mendapatkan data-data secara teori yang mendukung dalam pemograman basis data. Metode penelitian yang digunakan dalam penelitian ini adalah metode kualitatif dengan pendekatan deskriptif. Penelitian deskriptif merupakan yang mengumpulkan informasi mengenai status gejala yang ada, yaitu gejala yang didapat peneliti pada saat penelitian. Melalui metode ini peneliti melakukan metode penelitian lapangan dan penelitian kepustakaan.

3. Metode Kepustakaan

Pengumpulan data dan informasi dari kutipan-kutipan, serta hasil laporan dan bahan lainnya yng berkaitan dengan penelitian ini, dari bahan-bahan tersebut diambil teori yang dapat dijadikan landasan untuk menganalis yang dikemukakan dalam penelitian.

Dalam rangka melakukan perancangan sistem melakukan langkah-langkah sebagai berikut:

1. Identifikasi masalah

Peneliti melakukan identifikasi masalah yang dialami pada PT Maxindo Content Solution.

2. Analisis Kebutuhan

Peneliti melakukan analisis tentang masalah penggajian pada koperasi PT Maxindo Content Solution. 
3. Study pustaka

Peneliti melakukan riset tentang study pustaka untuk dijadikan landasan dalam melakukan penelitian tentang penggajian karyawan pada PT Maxindo Content Solution.

4. Pengolahan data

Peneliti melakukan pengolahan data dari penelitian yang telah peneliti lakukan pada PT Maxindo Content Solution.

5. Perancangan sistem

Peneliti melakukan perancangan sistem dari hasil penelitian yang telah peneliti lakukan.

6. Perancangan Aplikasi

Peneliti melakukan perancangan aplikasi dari perancangan sistem yang telah peneliti buat untuk digunakan pada PT Maxindo Content Solution.

7. Pengujian aplikasi

Peneliti melakukan pengujian aplikasi yang telah peneliti buat untuk PT Maxindo Content Solution sehinggaa berjalan sesuai dengan yang diharapkan.

8. Penelitian Laporan

Peneliti melakukan pengujian laporang yang telah peneliti buat untuk PT Maxindo Content Solution sehingga berjalan seusai dengan yang diharapkan.

\section{HASIL DAN PEMBAHASAN}

Menurut (Sukamto \& Shalahuddin, 2014) Data Flow Diagram atau dalam bahasa Indonesia menjadi Diagram Alir Data (DAD) adalah refresentasi grafik yang menggambarkan aliran informasi dan transformasi informasi yang diapilikasikan sebagai data yang mengatur dari masukan (input) dan keluaran (output). DFD tidak sesuai untuk memodelkan sistem yang menggunakan pemrograman berorientasi objek. Dalam merancang prosedur yang digunakan, peneliti menggunakan diagram konteks.

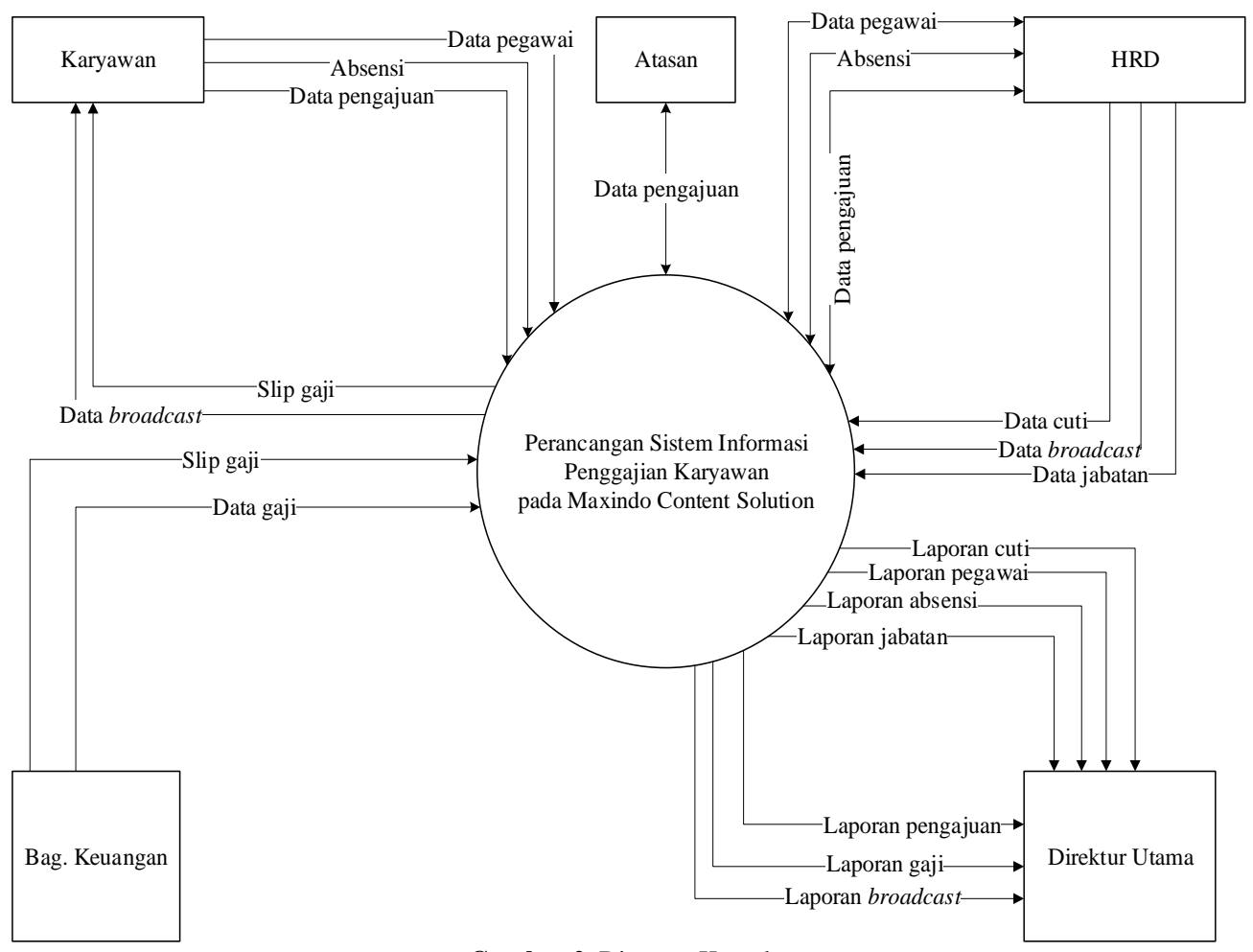

Gambar 2. Diagram Konteks

Menurut (Sukamto \& Shalahuddin, 2014) Entitiy Relationship Diagram adalah pemodelan awal basis data yang akan dikembangkan berdasarkan teori himpunan dalam bidang Matematika untuk pemodelan basis data relational. 


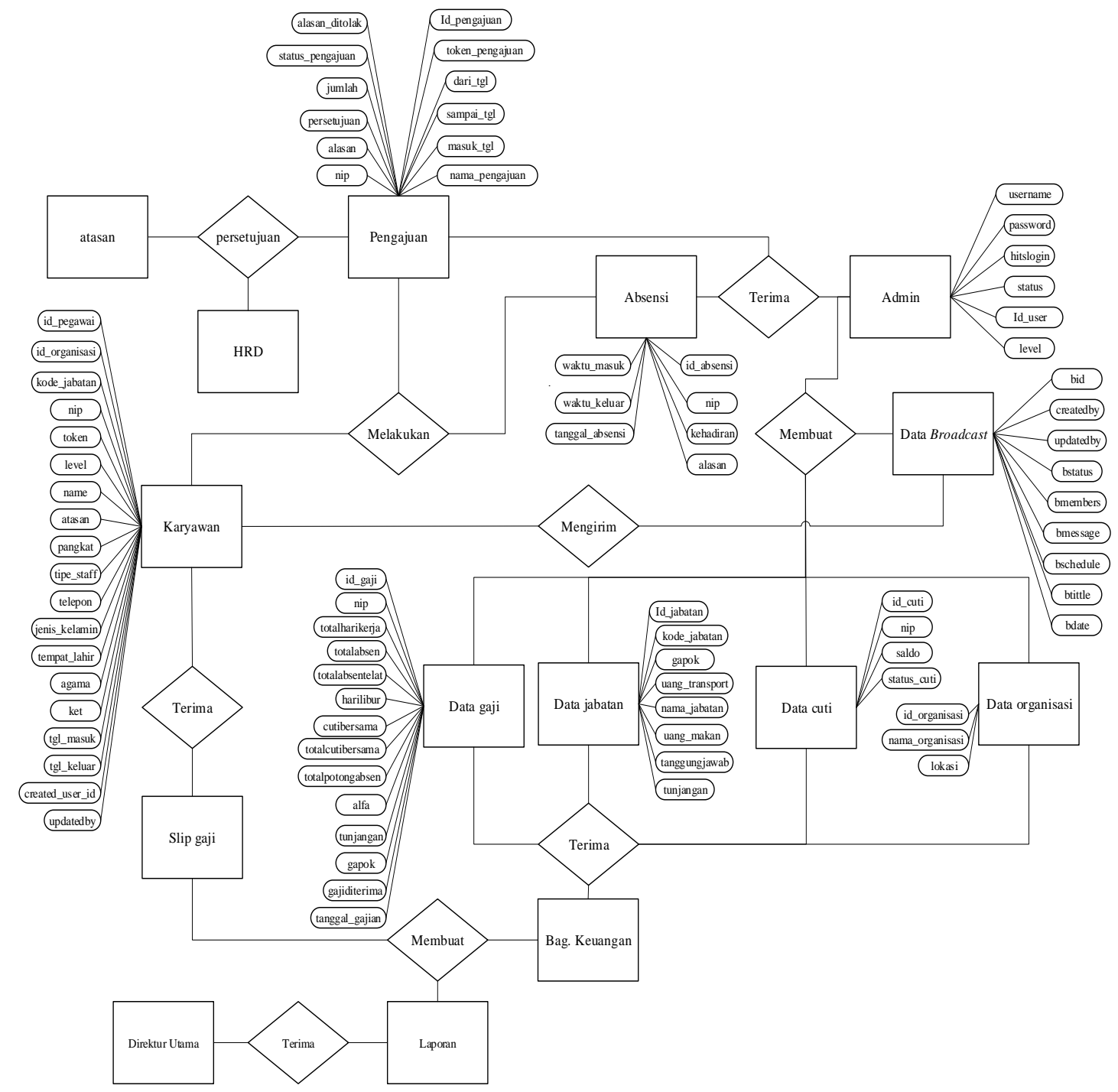

Tampilan Layar

Gambar 3. Entity Relationship Diagram (ERD)

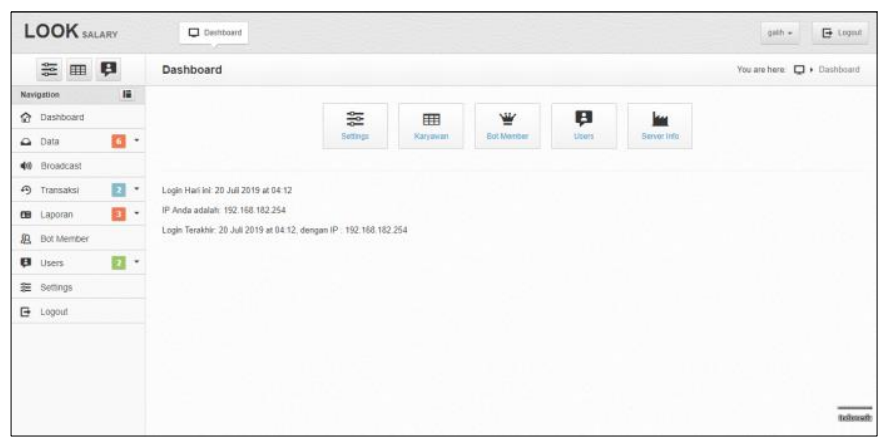

Gambar 4. Tampilan Menu Utama

Dalam Tampilan menu Utama akan menampilkan menu button Data, Broadcast, Transaksi, Bot Member, Data Karyawan, Settings, Log Out yang berfungsi untuk menampilkan menu selanjutnya sesuai dengan pilihan. 


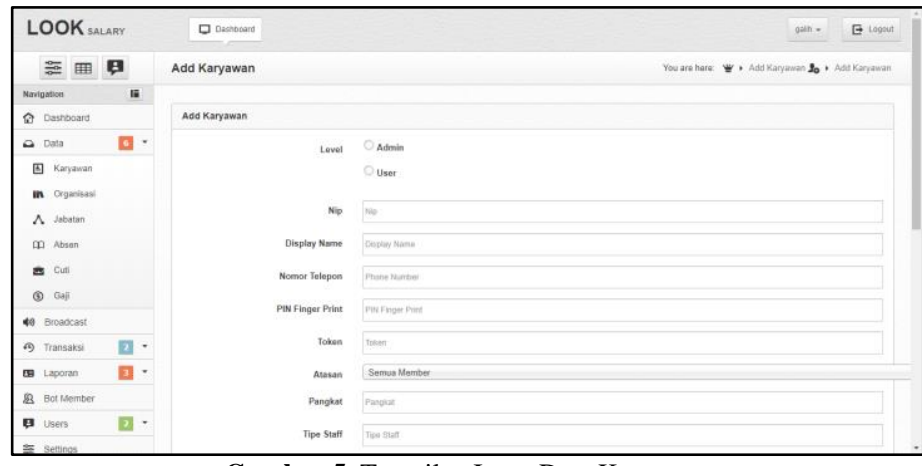

Gambar 5. Tampilan Input Data Karyawan

Tampilan input data karyawan akan melakukan penambahan data karyawan

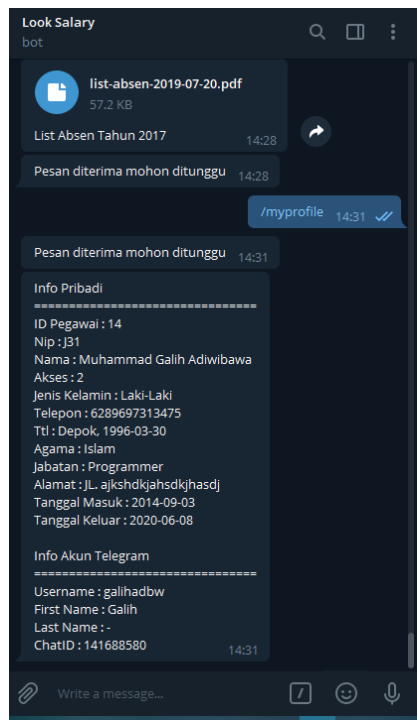

Gambar 6. Tampilan Form Profil

Tampilan form profil menampilkan detail keterangan data pegawai yang bersangkutan.

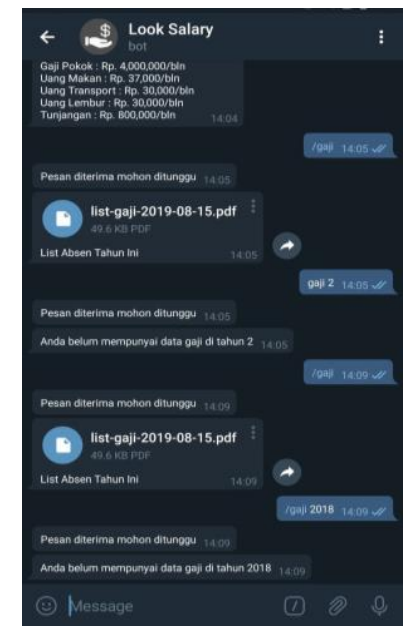

Gambar 7. Tampilan Form Gaji

Tampilan form gaji akan menampilkan keterangan detail tentang gaji pertahun yang diinginkan. 


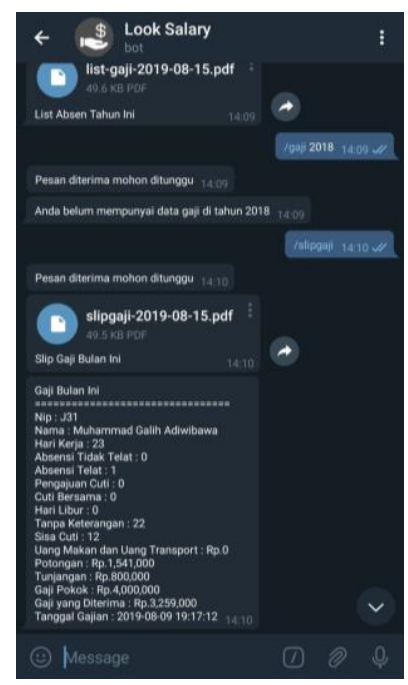

Gambar 8. Tampilan Slip Gaji

Tampilan form slip gaji akan menampilkan tentang keterangan gaji perbulan yang diinginkan.

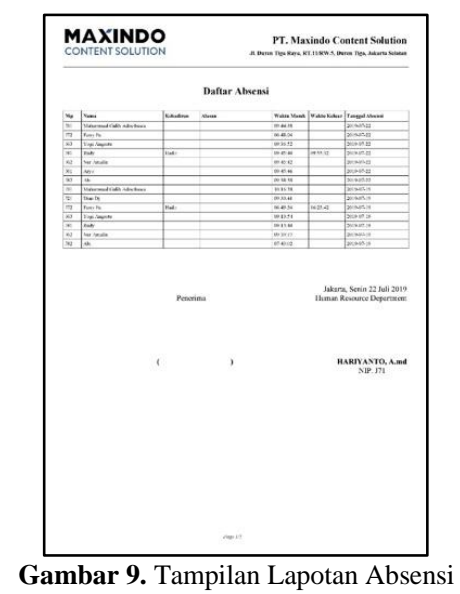

Tampilan laporan absensi berfungsi menampilkan laporan daftar absensi terhadapa karyawan yang bersangkutan.

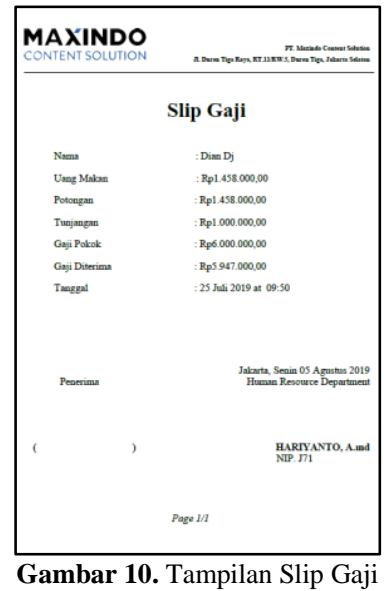

Tampilan laporan slip gaji berfungsi sebagai keterangan detail gaji karyawan yang bersangkutan. 


\section{SIMPULAN}

Berdasarkan data yang diperoleh selama penelitian, maka peneliti dapat mengambil kesimpulan bahwa dengan dilakukan pengembangan sistem pegganjian menjadi lebih efisien, efektif, dan data yang akurat. Setelah dilakukan perancangan sistem informasi penggajian pada PT Maxindo Content Solution dapat melakukan evaluasi pada sistem penggajian guna untuk memperoleh sistem penggajian yang lebih efektif dari sisi waktu, tenaga dan keamanan. Dengan diterapkannya Telegram Bot dan aplikasi berbasis web sistem informasi penggajian ini dapat mempercepat pengolahan data dan proses penghitungan gaji serta informasi yang dihasilkan lebih akurat. Setelah dilakukan pengujian aplikasi yang telah dirancang dapat memudahkan dalam pembuatan laporan yang dibutuhkan, diantaranya laporan pegawai, laporan penggajian, laporan absensi, laporan pengajuan, laporan jabatan, laporan cuti, laporan gaji, dan slip gaji secara cepat.

\section{DAFTAR PUSTAKA}

Anastasia, D., \& Lilis, S. (2011). Sistem Informasi Akuntansi, Perancangan, Prosedur dan Penerapan (Edisi 1). Andi Yogyakarta.

Azhe, W. (2018). Telegram: Sejarah Singkat dan Fitur-Fiturnya. Mi Community. https://c.mi.com/thread-724131-11.html.

Cokrojoyo, A., Andjarwirawan, J., \& Noertjahyana, A. (2017). Pembuatan BOT Telegram untuk Mengambil Informasi dan Jadwal Film Menggunakan PHP. Petra Christian University, Vol 5. No, 1. http://publication.petra.ac.id/index.php/teknik-informatika/article/view/5163

Ghifari, F., Rachmat, H., \& Atmaja, D. S. E. (2015). Design of Automation Inspection System Using Cluster Identification Method Based on Leather Shoes Colour at Venamon Corporation. E-Proceeding of Engineering, Vol.2, No., 2. https://libraryeproceeding.telkomuniversity.ac.id/index.php/engineering/article/viewFile/1871/1776

Laudon, K. C., \& Laudon, J. P. (2014). Sistem Informasi Manajemen Perusahaan Digital (Edisi 13). Penerbit Salemba Empat.

Malayu, H. (2012). Manajemen Sumber Daya Manusia. PT. Bumi Aksara.

Rochim, H. N. (2016). Rancang Bangun Telegram BOT pada Telegram Messanger dengan Metode Long Polling untuk Koperasi Kopma UGM. Universitas Gajah Mada. http://etd.repository.ugm.ac.id/index.php?mod=penelitian detail\&sub=PenelitianDetail\&act=view\&typ=html\&buku_id=93701\&obyek_id=4

Samsudin, M. (2010). Manajemen Sumber Daya Manusia. CV. Pustaka Setia.

Sukamto, R. A., \& Shalahuddin, M. (2014). Rekayasa Perangkat Lunak Terstruktur dan Berorientasi Objek. Informatika. Sutabri, T. (2012). Analisis Sistem Informasi. CV. Andi Offset. 